University of St. Thomas, Minnesota

UST Research Online

2012

\title{
Creating Entrepreneurial Opportunities as a Means to Maintain Entrepreneurial Talent in Corporations
}

Kevin L. Johnson

University of St. Thomas, Minnesota, John5258@StThomas.edu

Cindy Wu

Baylor University, Cindy_Wu@Baylor.edu

Follow this and additional works at: https://ir.stthomas.edu/ocbmgmtpub

Part of the Business Administration, Management, and Operations Commons

This Article is brought to you for free and open access by the Management at UST Research Online. It has been accepted for inclusion in Management Faculty Publications by an authorized administrator of UST Research Online. For more information, please contact asle4660@stthomas.edu. 


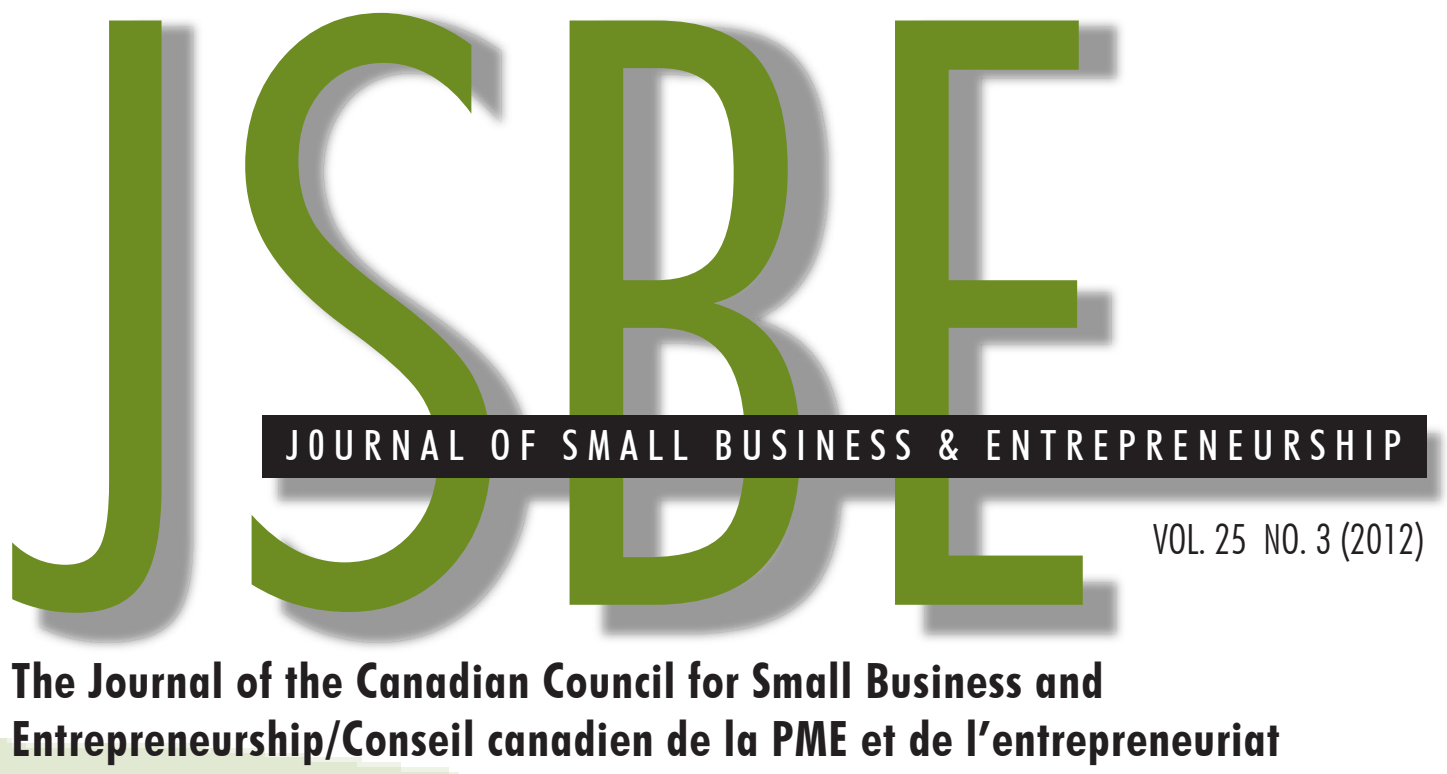

\section{INSIDE}

261 The Role of Attributional Explanatory Style in the Perceived Outcomes of Entrepreneurial Venture Failure Mary K. Askim-Lovseth and Richard A. Feinberg

283 Institutions and Micro-enterprises Demography: A Study of Selected EU Countries, 1997-2006

Pradip Kumar Biswas and Alberto Baptista

307 Innovativeness and Performance in Women-Owned Small Firms: The Role of Knowledge Acquisition

Matilde Ruiz-Arroyo, María del Mar Fuentes-Fuentes, Ana Maria Bojica and Lázaro Rodríguez-Arizao

327 Creating Entrepreneurial Opportunities as a Means to Maintain Entrepreneurial Talent in Corporations

Kevin L. Johnson and Cindy Wu

349 Démarches des dirigeants de PME pour améliorer leurs compétences à la suite d'une évaluation multisource Nancy Brassard and Normand Pettersen

357 How Do Entrepreneurs' Emotional Intelligence and Transformational Leadership Orientation Impact New Ventures' Growth? Ronit Yitshaki

375 Nascent Entrepreneurs Access and Use of Network Resources in a Technology Incubator

Steven Tello, Yi Yang and Scott Latham

399 Book Review: Tim Mazzarol and Sophie Reboud (eds.), Strategic Innovation in Small Firms

Chris Street 


\title{
Creating Entrepreneurial Opportunities as a Means to Maintain Entrepreneurial Talent in Corporations
}

\author{
Kevin L. Johnson, Opus College of Business, University of St. Thomas \\ Cindy Wu, Hankamer School of Business, Baylor University
}

\begin{abstract}
This paper considers how to retain the right talent to support corporate entrepreneurial interests such as internal corporate ventures by taking a new look at why individuals leave corporations and become entrepreneurs. We sought to first examine why entrepreneurs leave. The job satisfaction model tests the popular belief that individuals quit due to dissatisfaction. This is compared to the person-environment (P-E) fit model that theorizes individuals are pushed away and pulled into environments that present a better fit. In all, 715 nascent entrepreneurs were compared with 399 employees by regression and graphic analyses. Contrary to conventional wisdom, we found that for these entrepreneurs, dissatisfaction does not precede the entrepreneurial exodus from established companies. Rather, the perceptions of their new venture's competitive certainty and financial certainty pull them into new business ventures. Implications and suggestions for the managers are discussed.
\end{abstract}

RÉSUMÉ. Cette étude examine la façon de conserver le talent nécessaire pour soutenir les intérêts de l'entreprise tel que l'intrapreneuriat en réexaminant les raisons pour lesquelles les individus quittent des entreprises et deviennent des entrepreneurs. En premier lieu, les auteurs ont examiné pourquoi les entrepreneurs quittent les entreprises. Le modèle de satisfaction au travail vérifie la croyance populaire selon laquelle les individus quittent l'entreprise parce qu'ils sont insatisfaits. Cela est comparé au modèle de la relation entre la personne et l'environnement (person-environment fit model) selon lequel les individus sont poussés à quitter un environnement et attirés vers un environnement qui correspond mieux à leurs besoins. En tout, 715 nouveaux entrepreneurs furent comparés à 399 employés à l'aide d'analyses graphiques et de régression. Contrairement à la croyance populaire, les résultats révèlent que l'insatisfaction ne précède pas l'exode d'individus des entreprises établies. Ce sont plutôt les perceptions qu'il est certain que la nouvelle entreprise sera concurrentielle et financièrement viable qui attirent les individus vers la nouvelle entreprise. S'en suit une discussion portant sur les conséquences pour les dirigeants d'entreprises et des conseils pour conserver le talent nécessaire.

\section{Introduction}

Whether traditional or corporate, entrepreneurship is seen as a creative process by which "opportunities to create future goods and services are discovered, evaluated, and exploited" (Shane, and Venkataraman, 2000: 218). Because entrepreneurship is a channel for innovation and a driver for the change process (Schumpeter, 1934) and innovation is a key to creating a sustainable advantage (Blumentritt, and Danis, 2006), it benefits both corporations (McFadzean, O’Loughlin and Shaw, 2005) as well as the overall economy (Kirzner, 1997), and helps companies to increase their competitiveness.

Competition is intense in business today and managers need to find the balance between the stability of their existing businesses and the need to innovate into new businesses (Klavans, Shanley and Evan, 1985). Indeed, among the more interesting challenges for corporate managers is the attempt to develop a new business internally - an innovative pursuit called an internal corporate venture (ICV). ICVs come under the umbrella of corporate entrepreneurship (Sharma and Chrisman, 1999) and represent one of several business development activities.

Unfortunately, ICVs often fail to meet performance expectations, resulting in enormous business losses (Block, 1989; Garvin, 2004; Chesbrough, 2000; Campbell and Park, 2004). 
A variety of possible reasons for venture failures exist (see Hill and Hlavacek, 1977; Sommers and Koc, 1987; Murphy, Trailer and Hill, 1996; Arino and de la Torre, 1998; Sykes and Block, 1989). However, despite ongoing research to understand and improve venture performance, history is repeating itself (Birkinshaw, 2005). This may be in part due to not having the right people with the right talent for the venture. In fact, recent research associates having the right people with successful ventures (Shah, Zegveld and Roodhart, 2008). Thus, examined in this paper is how managers might retain the right people - the entrepreneurs - to support corporate entrepreneurship interests.

Given their skills and characteristics, entrepreneurs are viewed as one of the primary keys to successful entrepreneurship within corporations (Ensley, Pearson and Amason, 2002). Likewise, entrepreneurs may be the key for any company-large or small. However, there are corporate entrepreneurs and there are independent entrepreneurs. Like managers, entrepreneurs engage in marketing and financial control for their new ventures; however, independent entrepreneurs also engage in behaviors essential for successful entrepreneurship such as risk-taking and innovation (Chao, Greene and Crick, 1998), which critically distinguish them from managers, average employees, and corporate entrepreneurs (Thornberry, 2003). Unfortunately, these are the same people who are also screened out of the corporation (Block, 1982; Ross, 1987; Casson, 1982. Retaining such individuals is an important and understudied issue for corporate entrepreneurship. Furthermore, research that directly examines how to retain "entrepreneurs" has been scarce. The focus of this study is on nascent entrepreneurs (NEs) who choose to pursue external opportunities (rather than internal development opportunities), and how corporations might retain them. NEs were an appropriate sample because they are at the earliest stage of developing their businesses, which is also the point of the entrepreneurial decisions to be examined.

\section{Study Development}

This study intersects the areas of corporate strategy and human resource management. Specifically, it endeavors to help improve ICV success by focusing on a specific issue identified in extant human resource management research - the right people. The rich literatures on employee turnover and person-environment fit (P-E fit) were reviewed to develop this study and inform the hypotheses. For example, the classic employee turnover model (Mobley, 1977) suggests that job dissatisfaction is a precursor to voluntary turnover, which could imply that entrepreneurs decide to start their businesses because of job dissatisfaction. Unfortunately, studies specifically examining the impact of job satisfaction on entrepreneurs have been dated and suffered from recall errors (Brockhaus, 1980; Powell and Bimmerle, 1980; Shapero and Sokol, 1982). Furthermore, because of the cognitive and motivational differences between entrepreneurs and other employees (Johnson, Danis and Dollinger, 2008; Simon, Houghton and Aquino, 2000; Baron and Markman, 2003; Shane, Locke and Collins, 2003), entrepreneurs may be part of populations for whom job satisfaction does not precede turnover (Lee et al., 1996). Similarly, P-E fit literature (Judge and Ferris, 1992) might provide an alternative explanation for why these entrepreneurs leave the corporate positions to pursue their own ventures - because they perceive a better fit by doing so. It may be that entrepreneurs perceive a misfit from the corporation, and meanwhile a fit in the business environment, thus both push and pull forces drive their business ventures. This possibility is also tested.

This study contributes to the literature on entrepreneurship, employee turnover, and corporate entrepreneurship as follows: Firstly, it tests the applicability of conventional be- 
liefs in explaining an employee's decision to become an entrepreneur by using a group of NEs. NEs can provide a more current perspective on their corporate job experiences. Secondly, by also using the P-E fit theoretical model, the study potentially gains additional insights by examining both push and pull factors. Thirdly, by comparison, the study seeks better understanding of the entrepreneurial decision. Lastly, the results add incrementally to the current understanding of entrepreneurship, employee turnover, and corporate entrepreneurship; and, have managerial implications for business development strategies and human resource policies.

\section{Theoretical Framework and Hypotheses}

\section{Satisfaction Model}

Perhaps the simplest and most common theory is that people discontinue their job as a result of dissatisfaction. Individual entrepreneurship can come about to address a negative situation such as job dissatisfaction, as well as to exploit opportunities, or to meet financial or personal goals (Stewart et al., 2003; Cromie, and Hayes, 1991). Mobley (1977) suggests that, although distally related, job dissatisfaction is a precursor to employee turnover. Meta-analytical studies confirmed a negative relationship between job satisfaction and turnover (Hom and Griffeth, 1995; Griffeth, Hom and Gaertner, 2000). The average correlation reported across 42 studies in the 1990s, however, was only modest $(r=-0.19)$ with general job satisfaction being the strongest turnover predictor (Griffeth, Hom and Gaertner, 2000). Carsten and Spector (1987) contended that possible explanations, such as occupational and temporal differences, could contribute to the moderate relationship. Whether this satisfaction-turnover relationship also applies to entrepreneurs is an empirical question to be examined.

Entrepreneurs have been reported to differ from others in several critical aspects related to decision-making, including innovative cognitive styles, (Johnson, Danis and Dollinger, 2008; Simon, Houghton and Aquino, 2000), cognitive bias toward risk (Simon, Houghton and Aquino, 2000), and less rationality in their decision-making (Busenitz and Barney, 1997). These differences in decision-making and cognitive styles imply that a nascent entrepreneur's decision to leave the corporation may be different from the meta-analytical study findings based on mostly regular employees. These differences also provide additional reasoning to take a new look at the phenomenon. Using nascent entrepreneurs (NEs) also helps reduce the lag time between their entrepreneurial decision and experienced satisfaction; and, thus more precisely captures the relationship between the two.

Despite the suspicion that, with entrepreneurs, the decision to leave corporate may not be related to job dissatisfaction, "embarking on an entrepreneurial venture, however, depends upon the precipitating factors - such as, dissatisfaction, encouragement or the recognition of an opportunity" (McFadzean, O'Loughlin and Shaw, 2005: 357). It has long been established that the bureaucracy of the large corporation tends to hinder the entrepreneurial spirit through extended decision-making time, formal structures, or even standardized compensation practices (Klavans, Shanley and Evan, 1985; Luther, 1984), which leaves little room for the self-expression or personal growth of the nascent. In all, entrepreneurial pursuits due to their risky nature may be prohibited or not supported financially nor encouraged culturally within the corporation. Therefore, it is possible that these employees may feel pushed and it is this dissatisfaction that may ultimately lead to turnover, as depicted by early research on conventional turnover (see for example, Mobley, 1977). 
Hypothesis 1. The greater the dissatisfaction an individual has with their corporate job, the greater the likelihood the individual will decide to become an entrepreneur.

\section{Person-environment (P-E) Fit Model}

Even an organization that welcomes proactive and innovative employees may not be structured to support and encourage the autonomous behavior of entrepreneurial employees (Burgelman, 1983). In fact, corporate cultures tend to destroy entrepreneurship and produce bosses who have more concern for quarterly results than a commitment to entrepreneurial thinking (Thornberry, 2003). In exploring the decision to leave established corporations and become entrepreneurs, researchers have categorized two groups of factors: push and pull (Mallon, 1998; Shaver, 2004; Schjoedt and Shaver, 2007). Although the satisfaction model presents a compelling argument that entrepreneurs are "pushed" away because of dissatisfaction, the model is limited in that it: 1) only addresses push; 2) considers only one form of push; and 3) does not consider the potential "pull" from an external environment. Use of the person-environment fit (P-E fit) model can capture entrepreneurial employees leaving due to an internal misfit with the corporation and/or a better fit with an external environment.

Some conceptualizations of person-entrepreneurship fit suggest that entrepreneurs may be actively in quest of environments that support their new business aspirations (Baron and Markman, 2003). The "fit" perspective implies that entrepreneurs could be pushed from the corporation because of a misfit, or pulled into venturing because of external opportunities that better fit their aspirations. Despite the well-established theoretical and conceptual arguments of the fit model, empirical support is still required (Baron and Markman, 2003). Thus, contributing to the recent push-pull model of entrepreneurs' career choices (Schjoedt and Shaver, 2007), and building on the P-E fit model, this study examines whether entrepreneurs also leave because of the push generated from a misfit with the internal and/or the pull from a fit with the external.

The concept of "fit" has drawn much research attention in organizational behavior and human resource management (Arthur et al., 2006; Schneider, 2001; Kristof, 1996). The compatibility between people and environment has been explored and examined in various contexts, including people-organization fit (P-O fit) (Kristof, 1996), people-environment fit (P-E fit) (Judge and Ferris, 1992), people-vocation fit (P-V fit) (Holland, 1985), peoplegroup fit (P-G fit) (Guzzo and Salas, 1995), and most recently, person-entrepreneurship fit (Baron and Markman, 2003). Fit is of concern to researchers and practitioners alike because, in addition to job satisfaction, it relates to employee performance, organizational commitment, turnover, and psychological well-being (Arthur et al., 2006).

Although P-E fit is broadly defined as the compatibility between individuals and the environment, compatibility has been conceptualized in a variety of ways. One way to define P-E fit is based on the needs-supplies principle (Edwards, 1991). P-E fit could be established by selection and socialization. P-E misfit would lead to strains and attrition (Cable and Judge, 1994; Edwards and Harrison, 1993).

In summary, it may be that employees decide to start their own businesses because they are pushed out by internal conditions that do not address their needs or aspirations. Concurrently, they may be pulled into ventures because of irresistible opportunities in the external environment. The push and pull factors of this study are described next, followed by each respective hypothesis.

Internal entrepreneurial motivation (IEM). Because entrepreneurs tend to have greater needs for personal development, independence, and recognition, many corporations 
interested in internal venturing may seek to create environments that promote corporate entrepreneurship and autonomous entrepreneurial behavior (Birley and Westhead, 1994; Burgelman, 1984). Indeed, for these employees, a better fit is likely established with entrepreneurially oriented companies. Companies with an "entrepreneurial orientation" are competitively aggressive and believed to support entrepreneurship by encouraging or allowing autonomy, innovation, proactiveness, and risk-taking behavior (Covin and Slevin, 1991; Dess and Lumpkin, 2005). Nascent entrepreneurs have entrepreneurial aspirations, which creates a natural affinity to environments that offer autonomy, innovation, proactiveness, and risk-taking behavior. Indeed, entrepreneurship at any level includes, at a minimum, innovation and risk. Thus, entrepreneurial orientation allowed a theoretical link to the environmental influence as it relates to individual aspirations of entrepreneurs. Building from the entrepreneurial orientation construct that assesses a firm's orientation, a measure was derived to specifically assess aspirations of innovativeness, risk, and autonomy for individuals. This is referred to as their internal entrepreneurial motivation (IEM). A lack of these needs and aspirations being met in the corporate environment represents a push and should manifest in a greater motivation for exodus.

Some important elements for an entrepreneur that reflect their internal entrepreneurial motivation (IEM) include the opportunity to be innovative, to build wealth, to be able to take on the risks of new business challenges, and to have the freedom/autonomy to do things their way. Consider, for example, the item "...a chance to build great wealth or a very high income." If the employee does not perceive this opportunity within the corporation, then, provided that these items capture the needs of entrepreneurially minded employees, it would generate incongruence between the environment and the needs of the individual (P-E misfit), resulting in a push effect. Thus, these individuals are more likely to feel compelled to pursue their own businesses. Therefore, combined with the presumed failure of the corporate environment to provide fit, the individuals leaving corporations to pursue their own start-up will report a greater level of IEM.

Hypothesis 2. The greater the internal entrepreneurial motivation (IEM), the greater the likelihood the individual will decide to leave the corporate environment.

External entrepreneurial support (EES). In addition to the internal environment discussed, the P-E fit model also suggests that entrepreneurs are pulled into venturing because they perceive a better fit with the external environment. According to the needs-supplies perspective of P-E fit, an environment that attracts entrepreneurs would be one that provides favorable resources for venturing. Launching a venture requires crucial elements such as capital, labor, equipment, and, of course, customers (Shane and Venkataraman, 2000). Based on the finding that some geographical regions offer more entrepreneur-friendly environments than others (Fischer and Reuber, 2003), literature on entrepreneurial climate specifically attempts to identify factors that constitute this favorable environment for a new venture (Carter, Reynolds and Gartner, 2004; Matthews and Human, 2004). Utilizing established measures, three dimensions were identified for "external entrepreneurial support" (EES): community support, financial certainty, and competitive certainty.

Community support is directly derived from the entrepreneurial climate construct (Gartner et al., 2004). Regions, states, or nations have incentives to provide support for new business formation because the vitality of these activities is positively related to the health of an economy (Baumol, 1990). Early empirical evidence suggests that the support businesses receive from a community is a precondition for economic development (Putnam, Leonardi and Nanetti, 1993). Practices such as tax incentives, and venture training and development programs that are embodied in norms and networks of civic engagement 
seem to provide a more favorable entrepreneurial climate (Carter, Reynolds and Gartner, 2004). Such a climate includes an environment in which those with successful businesses receive admiration and have the support of communities and investors (Carter, Reynolds and Gartner, 2004). Krueger and Brazeal (1994) conclude that social and cultural support and tangible resources in the environment prepare a fertile ground for potential entrepreneurs to perceive a viable opportunity.

In addition to community support, financial and competitive certainty in the environment would favorably influence one's decision to leave the security of a corporation for a risky venture (Matthews and Human, 2004). Venture risks are particularly associated with the challenges of securing financial capital, as well as customers and other marketspecific factors (Shane and Venkataraman, 2000; Lee, Lee and Pennings, 2001; Chrisman, Bauerschmidt and Hofer, 1998). However, entrepreneurs are generally more optimistic than most (Cooper, Woo and Dunkelberg, 1988), which may make them more tolerant of uncertainty. Nevertheless, too much uncertainty associated with a new venture could signal a greater likelihood of failure and be seen as a deterrent to leaving the security of an established corporation. As a result, the greater the perceived financial and competitive certainty, the higher the likelihood of a positive pull that persuades employees to start their own businesses.

Overall, this study examines three dimensions of the external environment: the NEs' perceptions of a supportive community and the optimism of the NEs in terms of the perceived certainty (financial and competitive) of the external environment. Tests are conducted to determine if an above average perception of the external resources exists amongst entrepreneurs.

Hypothesis 3a. Among nascent entrepreneurs there will be above average perceptions of community support in the external environment.

Hypothesis 3b. Among nascent entrepreneurs there will be above average perceptions of financial certainty in the external environment.

Hypothesis 3c. Among nascent entrepreneurs there will be above average perceptions of competitive certainty in the external environment.

\section{Methods}

\section{Data Collection Procedures and Sample Details}

Analyses were conducted using the Panel Study for Entrepreneurial Dynamics (PSED) dataset which comprises one of the most representative samples of individuals in the early process of creating new businesses (Reynolds, 2000). PSED, which was collected by a consortium of known entrepreneurship scholars supported by the Kaufmann Foundation, contained the question items that were suggested by these researchers and included based on theory. All the variables we tested were extracted from the first PSED data collection phase at the time of manuscript drafting and later updated with the cleaned data. The PSED identified a sample of nascent entrepreneurs (NEs) using random telephone dialing combined with surveys across the United States. The NEs represented individuals who had committed to starting a new business within the past year, were still in the early stages of development, but had not yet generated profits. Subsequent data collection phases allow for the follow-up analyses of the performance and success rates of the ventures for those conducting longitudinal studies; however, for this study, the response of the nascent as 
close to the point of the initial decision as possible to leave an established corporation and pursue a new venture was crucial.

Also identified was a comparison group (CG) composed of those who continued to work with established corporations. Lastly, a small group of 60 nascent intrapreneurs (NIs) who stayed and worked on internal ventures was also identified. Since the focus was on those who decided to leave the corporation - and the NIs continued to work with the corporation - the NIs were by definition part of the comparison group of individuals who chose to stay. However, given an alternative argument that both NEs and NIs are "entrepreneurial," the robustness and sensitivity of the analyses were checked by both including and excluding the NIs. In each case, the results held with the same significance and nearly identical effect sizes.

According to the creators of the PSED dataset: "The design of the sample is based on two critical factors: the definition of the population of interest and the method by which elements in that population are selected" (Gartner et al., 2004: 487). If a representative sample is obtained by the dataset, the results are generalizable to the population. In practice, however, sampling procedures, even in the absence of systematic biases, do not provide an ideal representation of the population ages and gender. As a result, sample weight calculations were provided in the PSED to "correct the sample distributions so that they match information contained in the U.S. census" (Gartner et al., 2004: 489). Accordingly, we applied the weighting procedures to account for differences in sample design and nonresponse (Gartner et al., 2004: 489). This procedure yielded 715 NEs and a CG of 399. The NE group was composed of 455 males and 260 females, and the CG was composed of 176 males and 223 females.

In terms of seriousness of their start-up intentions, approximately $75 \%$ indicated that a business plan was in process and 19\% indicated that a start-up team would be organized. When asked whether their venture represented an independent start-up, corporate sponsor, franchise/multi-level marketing, purchase/takeover, or other, 95\% indicated an independent start-up, about 3\% indicated a purchase/takeover, and about $2 \%$ indicated other.

The NEs averaged 17.5 years of paid full-time work experience with an average of eight years in managerial or supervisory work. Level of education was assessed as: 1) up to the eighth grade; 2) some high school; 3) high school degree; 4) some college; 5) community college degree; 6) college degree; 7) graduate training; 8) Master's degree; and 9) doctoral degree. The most frequently reported (mode) educational level was "some college." The CG averaged 16.5 years of full-time work experience with seven years in managerial or supervisory work. Where teams were indicated, the start-up teams had an average of eight years of industry experience. Respondents ranged from 18 to 74 in age (18 to 93 in the CG) with the average age being 39 .

Respondents also indicated the business category of their respective ventures. The categories represented: 1) retail; 2) restaurant, tavern, and nightclubs; 3 ) consumer services; 4) health, education, and social services; 5) manufacturing; 6) construction and mining; 7) agriculture, forestry, and fishing; 8) wholesale distribution; 9) transportation; 10) utilities and communications; 11) finance and insurance; 12) real estate; and, 13) business consulting.

\section{Measures}

Job satisfaction. Job satisfaction was measured in reference to the respondent's current or most recent corporate job by the following item using a five-point Likert-type scale: How satisfied were you with this job (1: very dissatisfied; 5: very satisfied)? Although single- 
item measures are generally avoided because of their reduced reliabilities, research has already shown that this standard item is reliable and valid (Davis, 1999; Wanous, Reichers and Hudy, 1997). In fact, job satisfaction is one of the most widely studied constructs and can be either facet-specific or facet-free depending upon the research purpose and objectives. Research has shown that the single facet-free item is appropriate and well accepted when examining cognitive and affective reactions to job elements deemed most important to the subject (Wanous, Reichers and Hudy, 1997; Crites, Fabrigar and Petty, 1994). Also, meta-analytical research shows that general job satisfaction, rather than facet-specific satisfaction, is robust in predicting turnover (Griffeth, Hom and Gaertner, 2000) and therefore appropriate for this study.

Internal entrepreneurial motivation (IEM). The premise behind the IEM measure is the inference that if something is "truly" very important to an individual and the individual chooses to stay, then the environment probably provides it. Thus, if wealth creation is truly very important and the opportunity exists in the company, then the individual should stay in order to fulfill their aspiration. Conversely, if an entrepreneur chooses to leave, then the company probably does not provide what is truly valued by the entrepreneur.

This concept is supported by anecdotal evidence. For example, if on-site daycare service or flextime is more than desirable, but truly very important for a person and not provided, then chances are the employee will quit. The attribute could have been initially provided and cancelled, or perhaps developed later. Nevertheless, the outcome is the same - the employee will leave. Indeed, an architectural friend who truly aspired to do creative designs was instead required to work on standardized buildings such as warehouses. As a result, he left the firm in frustration. Another associate for whom a sense of justice and ethics was truly of paramount importance felt that the firm she was with was routinely unjust in its business dealings. She left the firm. In other cases, individuals who truly desired a sense of "making a difference" or accomplishment, changed careers or sacrificed larger salaries. For them, these things (or lack thereof) were truly important and motivational. Thus, we sought from the extensive set of PSED variables a measure based on the literature (Hornsby et al., 1993) and elements of entrepreneurship (Dess and Lumpkin, 2005) that reflected resources, opportunities, needs, or conditions, which in theory should be truly important to entrepreneurs.

Since the PSED dataset was constructed by a consortium of entrepreneurship scholars, many items were readily available with measures provided. Initially, nine available items in the database were selected that captured innovativeness, risk, autonomy, or an internal quality of achievement and recognition (Covin and Slevin, 1991; Dess and Lumpkin, 2005). Two items (1: to have the power to greatly influence an organization; and 2: to lead and motivate others) lacked face validity and better reflected a person's desire for power and leadership as opposed to an interest in entrepreneurially supportive environments that would motivate and support opportunities for aspiring entrepreneurs. These two items were therefore excluded. The final seven items yielded a Cronbach alpha of 0.75 , indicating good internal reliability (Table 1).

The nascent entrepreneurs (NEs) had indicated an interest in starting a new business, therefore the question posed to them was: "To what extent are the following reasons important to you in establishing this new business?" In contrast, the question posed to the comparison group was similar but without the reference to starting a new business: "To what extent are the following important to you in your decisions about your work and career choices?" Both responses were on a five-point Likert-type scale (1: to no extent; 5: to a very great extent). 


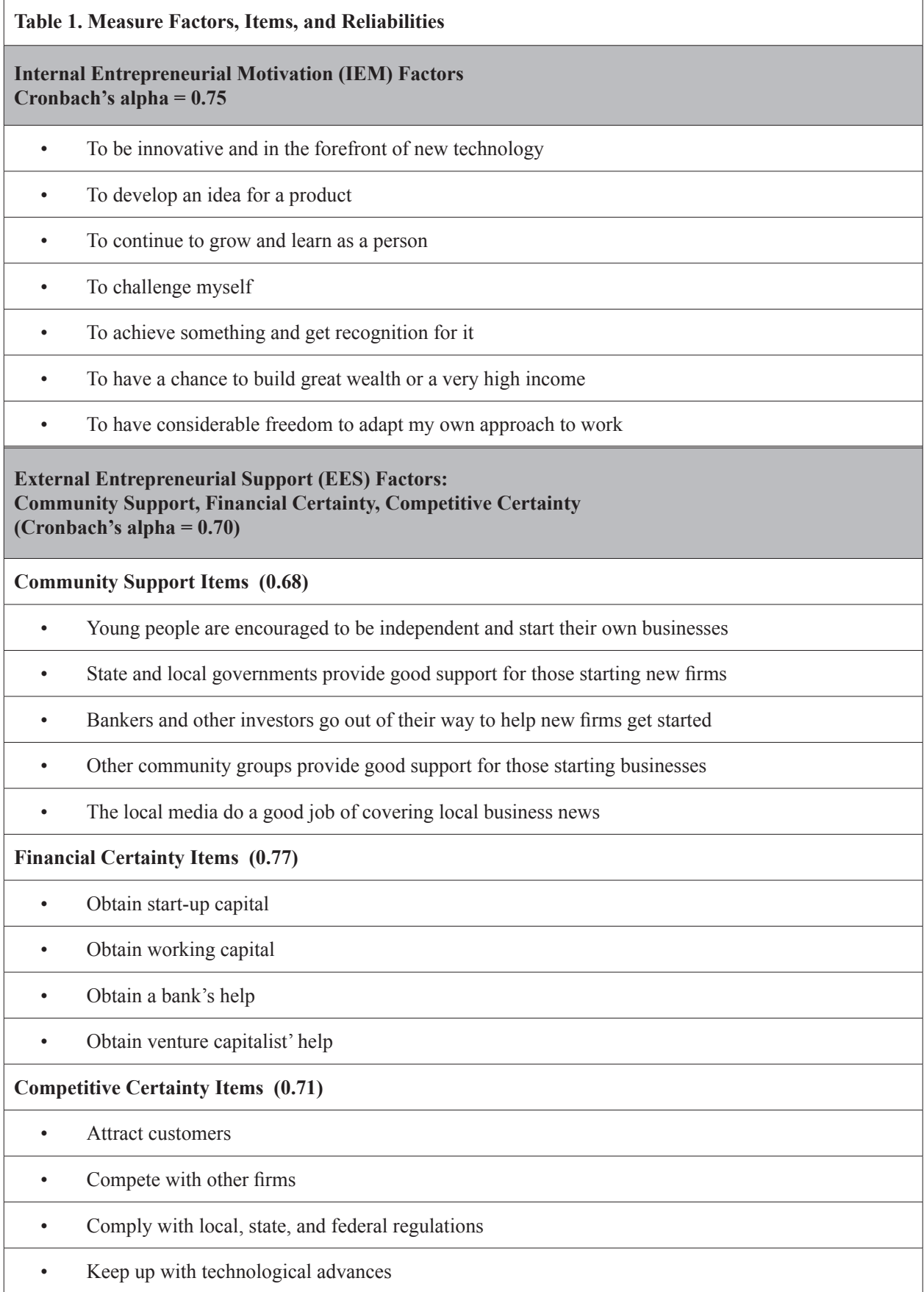

External entrepreneurial support (EES). The EES measure was composed of 13 items on three factors: community support, financial certainty, and competitive certainty. The community support factor was measured by obtaining the level of agreement or disagreement with five items on a five-point Likert-type scale. In contrast, both financial certainty 


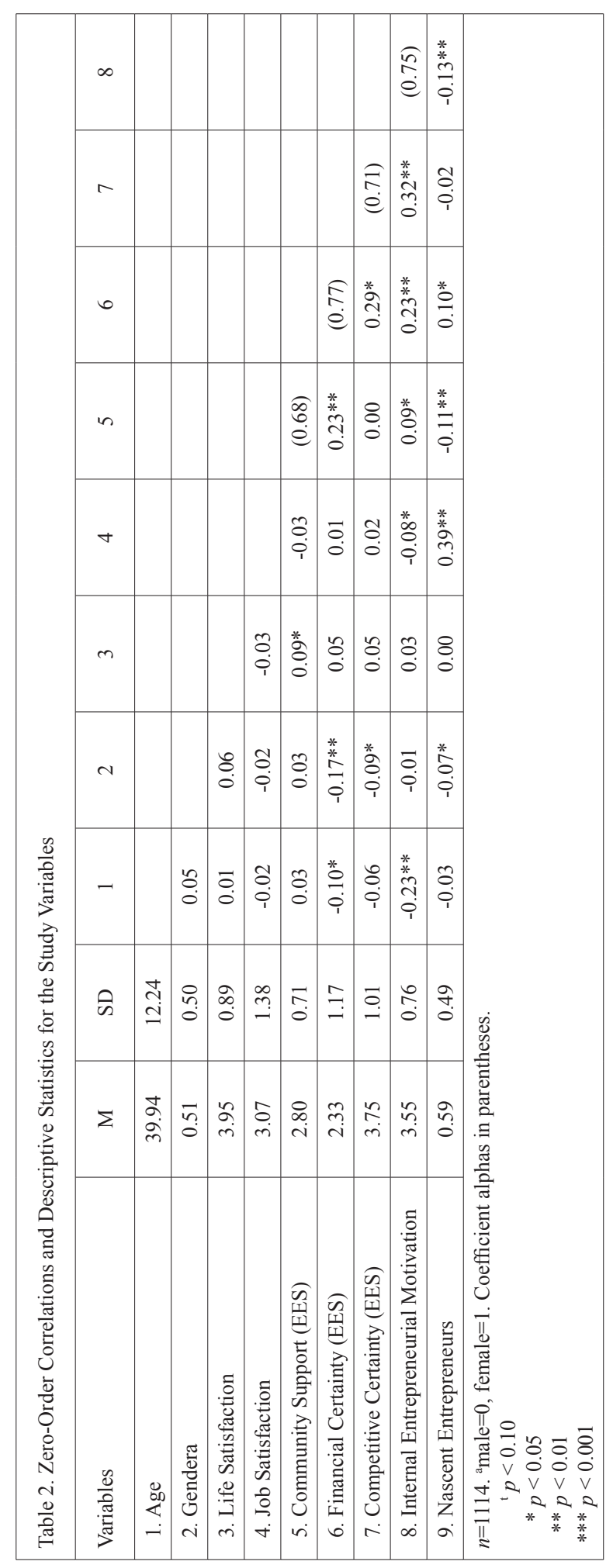


and competitive certainty pertain specifically to nascents pursuing a start-up. Therefore, financial and competitive certainty measures were only administered to the NEs. NEs were asked to answer eight questions on a five-point Likert-type scale (1: very low certainty; 5: very high certainty) with the instruction, "Considering the economic and community context for the new firm, how certain are you that the new business will be able to accomplish each of the following?" All 13 items were factor analyzed and correctly loaded with an overall Cronbach alpha of 0.70 (Table 1).

Control variables. Studies have shown that life and job satisfaction are circular, with each explaining a portion of variance (Cramer, 1995). This suggests that it is theoretically possible that life satisfaction influences one's job satisfaction. The desire to become an entrepreneur may also be associated with life satisfaction (Daily and Near, 2000). Given this potential confound, it was important to control for life satisfaction.

Life satisfaction was measured by the following item and responses on a five-point Likert-type scale: I am very happy with my life overall (1: completely untrue; 5: completely true). The appropriate conditions for use of a single-item measure for life satisfaction are well established and adhered to in this study (Gartner et al., 2004; Andrews and Withey, 1976; Fordyce, 1988; Larsen, Diener and Emmons, 1985). Lastly, due to possible difference in risk tolerances, controls were included for gender and age.

\section{Analyses and Results}

Table 2 displays means, standard deviations, and intercorrelations among the study variables. Binary logistic regression was used to test Hypotheses 1 and 2 regarding the start-up decision. Binary logistic regression is appropriate when the dependent variable is dichotomous and is applicable to a broader range of situations than basic discriminant analysis. One-sample t-tests and graphical analyses were used to test the third set of hypotheses regarding perceptions. The one-sample t-tests can be used to determine whether the mean differs from a specified value. The graphical analysis shows a closer examination and provides additional insight potential.

\section{Satisfaction Model Results}

Individuals with high current job dissatisfaction (reverse score of job satisfaction) were expected to be more likely to pursue new ventures than individuals with less dissatisfaction (Hypothesis 1). The results $(\operatorname{Exp}(B)=0.49, p<0.001)$ showed that the odds were indeed significant for dissatisfaction (Model 1, Table 3). For comparison, without the NIs as part of the CG, the results were: $\operatorname{Exp}(B)=0.43, p<0.001$. As expected, dissatisfaction also significantly contributed to the prediction. Interestingly, results were in the opposite direction hypothesized.

Reversed findings can be caused by an outlier; however, there were no outliers or other anomalies. We had a good representative sample, a large sample, and a very straightforward analytical technique. Thus, although NEs were expected to be the more dissatisfied employees, the data indicated that these individuals were in fact significantly happier with their jobs than those who stayed. We offer possible explanations of contrary results in the discussion.

\section{P-E Fit Model Results}

Internal entrepreneurial motivation (IEM) results. We hypothesized that individuals who reported greater IEM (push) would more likely pursue a new start-up given the failure of corporations to meet their aspirations. The results $(\operatorname{Exp}(B)=0.66, p<0.001)$ showed that 


\begin{tabular}{|c|c|c|c|c|}
\hline \multicolumn{5}{|c|}{ Model 1: Job Dissatisfaction } \\
\hline & $\mathrm{B}$ & S.E. & Sig. & $\operatorname{Exp}(B)$ \\
\hline Female & -0.07 & 0.16 & 0.65 & 1.08 \\
\hline Age & -0.01 & 0.01 & 0.77 & 1.00 \\
\hline Life Satisfaction & 0.05 & 0.09 & 0.60 & 1.05 \\
\hline Job Dissatisfaction & -0.71 & 0.06 & 0.00 & $0.49 * * *$ \\
\hline Constant & 2.05 & 0.48 & 0.00 & 7.75 \\
\hline \multicolumn{5}{|c|}{ Model 2: Internal Entrepreneurial Motivation } \\
\hline & $\mathrm{B}$ & S.E. & Sig. & $\operatorname{Exp}(B)$ \\
\hline Female & -0.02 & 0.15 & 0.89 & 0.98 \\
\hline Age & -0.01 & 0.01 & 0.30 & 0.99 \\
\hline Internal Entrepreneurial Motivation & -0.42 & 0.10 & 0.00 & $0.66 * * *$ \\
\hline Constant & 1.93 & 0.50 & 0.00 & 6.86 \\
\hline $\begin{aligned}{ }^{\mathrm{t}} p & <0.10 \\
* p & <0.05 \\
* * & <0.01 \\
* * * p & <0.001\end{aligned}$ & & & & \\
\hline
\end{tabular}

IEM was indeed significant (Model 2, Table 3). However, contrary to expectations, the analysis of the data showed that greater IEM was related to a lower likelihood of exodus.

External entrepreneurial support (EES) results. Here community support, financial certainty, and competitive certainty were examined. Financial certainty and competitive certainty were only relevant for, and therefore administered to, the NE group. One-sample t-tests and graphical analysis can be used to determine if the mean of a variable differs from a specified constant or expected value. Thus, if NEs are more likely to have a positive outlook, we should find significance above the expected value. The appropriate value represented a point of indifference (3.0). Indeed, each factor displayed strong significance for the NEs $(p<0.001)$.

Community support was administered to both the NEs and CG, and therefore we also conducted a two-sample t-test to examine whether a significant difference existed in these two groups of respondents' perceptions. The results in Table 4 indicate that NE and CG did not perceive their community support differently; therefore, community support did not appear to be a significant pull factor.

To further examine each EES (pull) factor in the absence of a consistent comparison group (in the cases of financial certainty and competitive certainty), we utilized a graphical and descriptive analytical approach of response patterns. The Journal of Computational and Graphical Statistics published by the American Statistical Association (an authority in statistical techniques) is devoted to extending the use of graphical methods in statistics. Although an often-misunderstood technique, graphical analysis is among the oldest and most versatile of analytical techniques and has long been used and accepted in a variety of research (Chan, Makino and Isobe, 2006; Schmidt, 1997; Ware, 1973; Bernstein and Cowden, 1937; Ruamsook, Russell and Thomchick, 2007). The technique was applied here to provide an additional look at EES after significant t-tests results had been demonstrated. 


\begin{tabular}{|c|c|c|c|c|c|c|}
\hline \multicolumn{7}{|c|}{ One-sample t-Test of Means: Test Value $=3$} \\
\hline & $t$-value & df & $\begin{array}{c}\text { Sig. } \\
\text { (2-tailed) }\end{array}$ & $\begin{array}{c}\text { Mean } \\
\text { Difference }\end{array}$ & \multicolumn{2}{|c|}{$\begin{array}{l}95 \% \text { Confidence Interval of } \\
\text { the Difference }\end{array}$} \\
\hline \multicolumn{7}{|c|}{ Nascent Entrepreneur Group } \\
\hline EES - Community Support & -7.535 & 419 & 0.000 & $-0.26560 * * *$ & -0.3349 & -0.1963 \\
\hline EES - Financial Certainty & -8.960 & 394 & 0.000 & $-0.42060 * * *$ & -0.5129 & -0.3283 \\
\hline EES - Competitive Certainty & 15.542 & 422 & 0.000 & $0.74851 * * *$ & 0.6538 & 0.8432 \\
\hline \multicolumn{7}{|c|}{ Comparison Group } \\
\hline EES - Community Support & -1.767 & 306 & 0.078 & $-0.07101^{t}$ & -0.1501 & 0.0081 \\
\hline $\begin{aligned}{ }^{\mathrm{t}} p & <0.10 \\
* p & <0.05 \\
* * p & <0.01 \\
* * * p & <0.001\end{aligned}$ & & & & & & \\
\hline
\end{tabular}

Community support results. As aforementioned, although a one-sample t-test that tests the mean community support against the theoretical mean shows significance, the twosample independent t-test that compares the NE and CG did not show such difference. Since community support was administered to both groups, the two-sample t-test result is more appropriate. Therefore, we concluded that community support is not a strong pull factor. Comparatively, results indicated that NEs more often perceived higher support in the community for start-up activities than the $\mathrm{CG}$ (Mode: $\mathrm{CG}=2.6 ; \mathrm{NE}=2.8$ ). The analysis is further refined by comparing the calculated community support indifference point (actual mean $=2.74)$ to the mode $($ mode $=2.80)$. In total, although the perception regarding community support was relatively greater among NEs, it did not appear to be a strong pull factor given that the majority of the NEs indicated little difference from the mean (delta $=$ +0.06 ).

Financial certainty results. Given the statistical significance of the t-test, the perception of the majority of NEs was further probed. To do this, one does not examine the mean alone (a natural tendency) but what value was reported most frequently (the mode) (Albright, Winston and Zappe, 1999). Statistically, unlike the mean and median, the mode can be used to examine nominal data. For a more complete interpretation of the graphical analysis, the mean, median, and skew values are also reported for the certainty variables.

Perceived financial certainty t-tests indicated significant differences from the theoretical mean $($ mean $=2.59, \mathrm{t}=-8.960, \mathrm{df}=394, \mathrm{p}<0.001$.). In addition, the mode (3.0) was substantially higher than the actual mean of 2.59 (delta $=+0.41)$, indicating a clear pull effect.

Competitive certainty results. For the final EES pull factor, results showed a very high mode of 4.25 for competitive certainty. The high mode combined with the positively significant $\mathrm{t}$-test results (mean $=3.80, \mathrm{t}=15.542, \mathrm{df}=422, \mathrm{p}<0.001$ ) indicated strong support. This factor also displayed a pronounced enough skew (-0.94) for visual identification. As with financial certainty, the mode was higher than the actual mean $($ delta $=+0.45)$ and even exceeded the initial indifference point. Based on the data, financial certainty and competitive certainty are both pull factors, with competitive certainty being the strongest factor in the nascent entrepreneur's decision. 
Figure 1. External Entrepreneurial Support (EES) as Perceived by Nascent Entrepreneurs - Financial Certainty Dimension $(\mathrm{N}=394)$ : Mean= 2.59, Median= 2.50, Mode= 3.00, Skewness $=-\mathbf{0 . 0 1 5}$, S.E. of Skewness $=0.123$

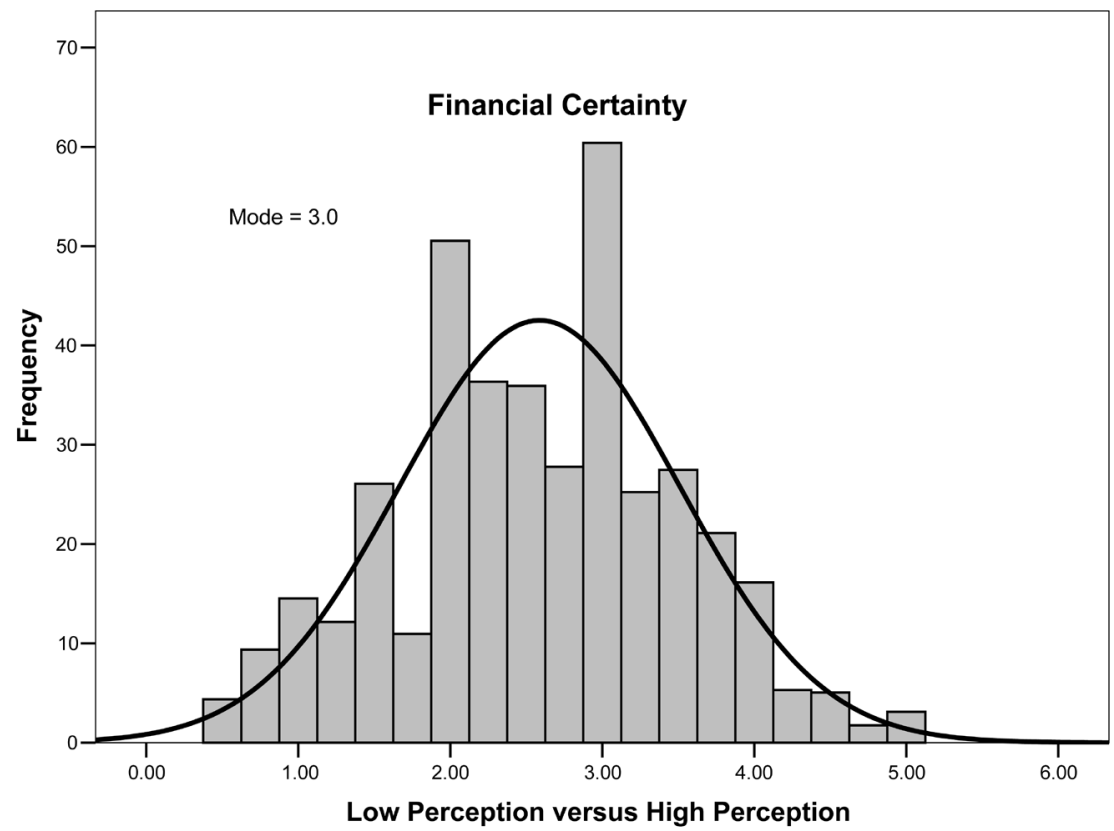

Figure 2. External Entrepreneurial Support (EES) as Perceived by Nascent Entrepreneurs - Competitive Certainty Dimension $(\mathrm{N}=387)$ : Mean=3.80, Median=4.00, Mode $=4.25$, Skewness $=-\mathbf{0 . 9 3 8}$, S.E. of Skewness $=\mathbf{0 . 1 2 4}$

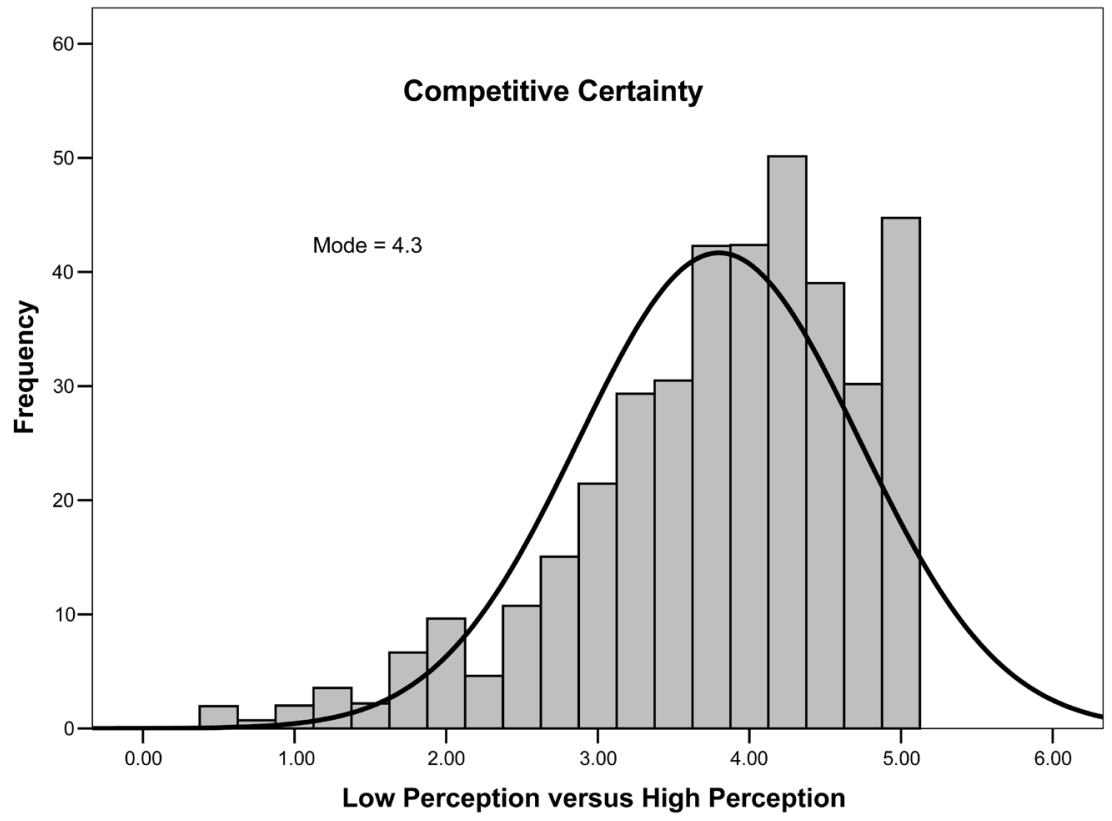




\section{Discussion}

Through the combined perspectives of strategy and human resources, this study seeks to enhance our understanding of why some individuals make the entrepreneurial decision to leave the corporation and pursue their own business; and, thus how we might retain them. Specifically, the study tested and compared two known theories: Job Satisfaction and P-E Fit.

\section{Job Satisfaction Results Discussion}

We suspected that entrepreneurs might be different from other employees in ways that challenge popular assumption, but based on the appeal of the classic employee turnover model we too expected lower job satisfaction to lead to the decision to leave a corporation. Despite conventional wisdom, some early research also considered the possibility that entrepreneurs may be a population for whom job satisfaction does not precede turnover (Lee et al., 1996). The PSED provided a rare opportunity to empirically test these theories on a large sample of nascent entrepreneurs. Indeed, the popular assumptions do not hold. NEs in fact leave the corporations with higher job satisfaction than the average employees.

A possible explanation for this counterintuitive finding may be that the companies in which the NEs work also represent the industries in which they hope to start their businesses. For instance, there are entrepreneurs who intentionally take positions in companies that serve the markets in which they intend to start their own businesses in order to learn more about the keys to success in the industry. Like internships for students, the experiences help the entrepreneurs determine if the industry is indeed one in which they would enjoy working. Thus, the entrepreneur confirms interest in the business, learns more about the industry, and eventually leaves to start the business. Consequently, it is not surprising that these entrepreneurs are happy and still leave to start their businesses — particularly in the same or a similar area as their previous job. Perhaps the conventional assertion based on turnover theory that job dissatisfaction pushes NEs away from established corporations is in need of refinement.

From another perspective, Stoner and Fry (1982) found among a group of 76 entrepreneurs that those who experienced job dissatisfaction tended to start new ventures in different areas than their previous job. Our findings are also consistent with a recent and similar study by Schjoedt and Shaver (2007) that took into consideration the NEs' anonymity in responses. Therefore, it may be that satisfied entrepreneurs become competitors and, as we have suggested, their previous corporate jobs serve as training grounds and provide a network for obtaining suppliers, customers, and the industry knowledge necessary to competitively pursue their ventures.

It also may be that these entrepreneurs have simply observed the corporation and now see an opportunity to do things differently. This type of thinking is known as the "Innovator." Recent research shows this style of thinking (Innovator versus Adaptor) is more likely among nascent entrepreneurs who also display high expectations (Johnson, Danis and Dollinger 2008). In other words, entrepreneurs are satisfied and convinced of their own ability to succeed where others failed. Thus, perhaps as an extension to Stoner and Fry's (1982) work, it could be that for NEs, job satisfaction reflects their optimism to take on greater challenges doing what they enjoy.

Finally, since our data were collected at a point closer to the entrepreneur's decision, it may have substantially reduced the errors in retrospectively reporting satisfaction - a common methodological shortcoming in earlier research (Cromie and Hayes, 1991; Brock- 
haus, 1982). In addition, because NEs are in the early stages of venturing, this data does not depend on the respondents' subjective report of intentions but allows higher objectivity. Furthermore, despite the traditional job turnover model that suggests a connection between job dissatisfaction and turnover (Mobley, 1977), alternative theories suggest that job dissatisfaction does not always precede turnover (Lee et al., 1996).

\section{P-E Fit Results Discussion}

The job satisfaction results alone could have raised more questions than they answered; however, in rechecking findings, and, using an independent measure of internal entrepreneurial motivation (IEM) and external entrepreneurial support (EES) driven by the strategy perspective and based on a different HR theory (the P-E fit model), we found additional support for the findings. Specifically, a stronger push did not create a greater likelihood of people leaving. Thus, the satisfied and aspiring entrepreneurs were remaining with established corporations for a period of time but eventually still leave. Why? The P-E Fit model provides additional insight.

The findings suggest that NEs are pulled into ventures because of beliefs in their ability to meet the competitive challenges. These challenges are best captured by competitive certainty and financial certainty. When they are optimistic about their new businesses' ability to compete in the business environment and obtain necessary funding, they dive into their ventures. This is consistent with a different yet relevant stream of research that suggests that individuals higher on entrepreneurial self-efficacy - the belief that one will be successful in performing the tasks of an entrepreneur - are more likely to become entrepreneurs (Chao, Greene and Crick, 1998). Thus, in combination with their elevated aspirations for wealth creation, growth, freedom, and recognition, their perceptions of certainty may provide the extra confidence for an already overly optimistic individual, thereby boosting their entrepreneurial self-efficacy leading to the eventual exodus from the corporation.

Put together, it is not their job dissatisfaction or the unsatisfied internal entrepreneurial motivation that drives them out of corporations, but the entrepreneur's outlook on the external environment and their optimistic perception of their own competitive advantage that ultimately drives this decision. It may be that they already have a venture in mind and simply need the right opportunity to move from idea to action. This is also consistent with the preliminary findings of Hills and Singh (2004).

What, then, do our results suggest that corporations might do if they want to retain the entrepreneurial talent within their organizations? Hulin, Roznowski and Hachiya (1985) contend that different populations place various levels of emphasis on the influences of job alternatives in the decision process. For example, employees who do not expect to stay with the organization for the long term weigh job opportunities particularly more in their decisions. Because entrepreneurial individuals may view their careers as more portable (Arthur and Rousseau, 1996) - that is, not limited to one particular organization - and manage their careers more proactively, favorable opportunities in the environment may weigh more in their decisions. Consequently, we suggest that it is in the best interest of executives to proactively replace corporate barriers with opportunities within for individuals to better exercise their entrepreneurial aspirations. In essence, the corporation should seek to create internal entrepreneurial opportunities that address the explicit motivations of the entrepreneur, and thereby enable entrepreneurship that can both maintain and attract entrepreneurial talent.

Specifically, corporations can facilitate opportunities for their entrepreneurially minded employees to pursue their ideas. The corporation can fully support and provide recognition 
for entrepreneurial ideas and achievements. Ironically, today corporations require individuals to sign away their rights to their ideas and discoveries in order for the corporation to control it as a potential competitive advantage. This myopic approach fails to recognize that the true source of the advantage is the employee in whose mind the innovations are made possible. Consequently, we propose that the employees should have ownership in their innovations, affording them the opportunity to build greater wealth, allow autonomy, and take risks and, therefore, the incentive to remain with the company as an ongoing source of potential competitive advantages. Examples of companies that reflect some of these ideas are Google, 3M, and Wegman Foods. Google is a well-known internet-based company that thrives on creative and innovative talent and indeed has a waiting list of applicants. $3 \mathrm{M}$ is known for allocating employees time to innovate. Wegman has a reputation of creating internal opportunities that attract independent entrepreneurs to return to the company.

\section{Limitations and Future Research}

This study relied upon data collected by the Panel Study of Entrepreneurial Dynamics (PSED). The use of an existing dataset constrains a study to the available variables. Also, the users of the dataset may not have full control over the psychometric properties of the variables as well as the sampling procedures. However, the PSED dataset, developed by the Kaufmann foundation in collaboration with many research scholars, contained many established variables and measures as well as details regarding the data collection and properties (see Reynolds, 2000). Still, not all available variables were ideal to the questions we asked thus requiring a search for acceptable proxies.

For example, the basic idea with the P-E fit model was that there are aspirations that if not met by the corporation would push the employee away due to a lack of fit. Alternately, P-E fit is established when the individuals' major needs and desires are addressed. Consequently, organizations could provide an environment with growth as well as interpersonal and task-related opportunities for the individual, in addition to the financial resources (Kristof, 1996). Thus, derived from the construct of entrepreneurial orientation to assess the entrepreneurial career aspirations for individuals, our measures relied upon the available PSED variables. Although developed independently, the internal entrepreneurial motivation variable showed strong reliability and was consistent with job satisfaction suggesting convergent validity.

Given the strong role of the external environment in pulling the entrepreneur out of the corporation, future research may wish to examine additional environmental factors. For instance, are entrepreneurs more likely to leave during economic downturns? If so, is it because of a decrease in competition or the loss of their corporate position? If not, is it because their perceptions are moderated by the strength of the economy or does financial uncertainty supersede competitive certainty during economic downturns? Should the retention strategies of corporations differ based on external environmental conditions (and if so how)? We encourage future research to pursue this promising line of research.

\section{Conclusion}

This research is motivated by the continued failure of ICVs (Birkinshaw, 2005) and arguments that having the right people is a key to ICV success (Shah, Zegveld and Roodhart, 2008). Given that independent entrepreneurs differ from managers, average employees and even corporate entrepreneurs (Thornberry, 2003), combined with the fact that independent entrepreneurs leave (Block, 1982), we wanted to examine turnover specifically 
in regards to the independent entrepreneurs. The goal is that managers might improve the performance and success of internal entrepreneurial pursuits by recognizing and retaining the independent entrepreneur.

By comparing two theoretical models, this study adds to our knowledge of entrepreneurial behavior; challenges some conventional wisdom; and advances our understanding of entrepreneurial behavior. This study differs from traditional entrepreneurship and turnover work in the specific focus on employees with strong tendencies and determination to start their own ventures. We believe these employees are different and require different management strategies. In fact, research has shown some facility with psychological and cognitive characteristics of entrepreneurs versus non-entrepreneurs as well as a connection between achievement orientation and performance (Johnson, Danis and Dollinger, 2008; Simon, Houghton and Aquino, 2000; Utsch and Rauch, 2000). Also, the entrepreneur career views may lend greater impact to favorable external opportunities on their decisions to leave corporate jobs (Arthur and Rousseau, 1996), and that influences on career decisions may vary across populations (Griffeth, Hom and Gaertner, 2000; Hulin, Roznowski and Hachiya, 1985). The entrepreneurial employees may also leave the corporation for reasons different from other employees. This has important implications since the success of ICVs might depend on these untapped entrepreneurs.

CEOs and other business development managers will attest, "As infuriating as the differences can be to both sides [existing business versus new venture], it is in the best interest of corporations to support employees who want to start new businesses" (DeSimone et al., 1995: 188). Although it may be that executives cannot always prevent the exodus of their entrepreneurs, they can still identify these individuals, understand their aspirations, and invest in them. They might assign the entrepreneur to a separate venture unit based on the guidelines addressed by recent research (Shah, Zegveld, and Roodhart, 2008). Channeling the entrepreneurial behavior into an opportunity to create a complementary business partner instead of a competitor would ultimately contribute to stability and innovative growth for established corporations. Finally, this study illustrates the value of different theoretical lenses to examine a phenomenon and advance research to provide valuable information for managers that pursue corporate entrepreneurship for which the right people must be found and retained.

\section{Acknowledgment}

The Ewing Marion Kauffman and the National Science Foundation for the development of the PSED Dataset provided funding for this project. Equal contribution of the authors listed. We would also like to acknowledge the guidance of Dr. Jeff Covin and the suggestions of several anonymous reviewers in the development and write-up of this research.

\section{Contact}

For further information about this article, contact:

Kevin L. Johnson, Assistant Professor of Management, Opus College of Business, University of St. Thomas, Minneapolis - St. Paul, MN 55403

Tel: 651-962-5431

Fax: 651-962-5093

E-mail: John5258@StThomas.edu 
Cindy Wu, Associate Professor of Management, Hankamer School of Business, Baylor University, One Bear Place \#98006, Waco, TX 76798-8006

Tel: $254-710-7672$

Fax: 254-710-1093

E-mail: Cindy_Wu@Baylor.edu

\section{References}

Albright, S., W. Winston, and C. Zappe. 1999. Managerial Statistics. Duxbury Press: California.

Andrews, F., and S. Withey. 1976. Social Indicators of Well-being: American's Perceptions of Life Quality. Plenum: New York, NY.

Arino, A., and J. de la Torre. 1998. "Learning from Failure: Towards an Evolutionary Model of Collaborative Ventures." Organization Science 9(3): 306-325.

Arthur, W., S. Bell, A. Villado, and D. Doverspike. 2006. "The Use of Person-organization Fit in Employment Decision Making: An Assessment of its Criterion-related Validity." Journal of Applied Psychology 91(4): 786-801.

Arthur, M., and D. Rousseau. 1996. "A Career Lexicon for the 21st Century." Academy of Management Executive 10(4): 28-39.

Baron, R., and G. Markman. 2003. "Beyond Social Capital: The Role of Entrepreneurs' Social Competence in their Financial Success." Journal of Business Venturing 18(1): 41-60.

Baumol, W. 1990. "Entrepreneurship: Productive, Unproductive, and Destructive." Journal of Political Economy 96(1): 893-920.

Bernstein, E., and D. Cowden. 1937. "Graphic Presentation of Trend Data.” Southern Economic Journal 3(4): 443-451.

Birkinshaw, J. 2005. “The Secret Diary of Corporate Venturing.” Business Strategy Review 16(2): 19-24.

Birley, S., and P. Westhead. 1994. "A Taxonomy of Business Start-up Reasons and their Impact on Firm Growth and Size." Journal of Business Venturing 9(1): 7-31.

Block, Z. 1982. “Can Corporate Venturing Succeed?” Journal of Business Strategy 3(2): 21-33.

Block, Z. 1989. "Damage Control for New Corporate Ventures.” The Journal of Business Strategy 10(2): 22-28.

Blumentritt, T., and W. Danis. 2006. "Business Strategy Types and Innovative Practices.” Journal of Managerial Issues 18(2): 274-291.

Brockhaus, R. 1980. "The Effect of Job Dissatisfaction on the Decision to Start a Business." Journal of Small Business Management 18(1): 37-55.

Brockhaus, R. 1982. "The Psychology of the Entrepreneur.” In C.A. Kent, D.L. Sexton, and K.H. Vesper (eds.), Encyclopedia of Entrepreneurship 40. Prentice Hall: Englewood, Cliffs, NJ.

Burgelman, R. 1983. "A Process Model of Internal Corporate Venturing in the Diversified Major Firm." Administrative Science Quarterly 28: 223-244.

Burgelman, R. 1984. "Designs for Corporate Entrepreneurship in Established Firms." California Management Review 26(3): 154-166.

Busenitz, L., and J. Barney. 1997. "Differences Between Entrepreneurs and Managers in Large Organizations: Biases and Heuristics in Strategic Decision Making." Journal of Business Venturing 12: 9-30.

Cable, D., and T. Judge. 1994. "Pay Preferences and Job Search Decisions: A Person-Organization Fit Perspective." Personnel Psychology 47(2): 317-348.

Campbell, A., and R. Park. 2004. "Stop Kissing Frogs.” Harvard Business Review 82(7): 27-28.

Carsten, J., and P. Spector. 1987. "Unemployment, Job Satisfaction, and Employee Turnover: A Meta-analytic Test of the Muchinsky Model.” Journal of Applied Psychology 72: 374-381.

Carter, N., P. Reynolds, and W. Gartner. 2004. "Perceptions of Entrepreneurial Climate.” In W.B. Gartner, K.G. Shaver, N.M. Carter, and P.D. Reynolds (eds.), Handbook of Entrepreneurial Dynamics: The Process of Business Creation. Sage: Thousand Oaks, CA.

Casson, M. 1982. "The Entrepreneur: An Economic Theory.” Martin Robertson: Oxford.

Chan, C., S. Makino, and T. Isobe. 2006. "Interdependent Behavior in Foreign Direct Investment: The Multi-level Effects of Prior Entry and Prior Exit on Foreign Market Entry." Journal of International Business Studies 37: 642-665.

Chao, C., P. Greene, and A. Crick. 1998. "Does Entrepreneurial Self-efficacy Distinguish Entrepreneurs from Managers?" Journal of Business Venturing 13(4): 295-316.

Chesbrough, H. 2000. "Designing Corporate Ventures in the Shadow of Private Venture Capital." California Management Review 42(3): 31-49.

Chrisman, J., A. Bauerschmidt, and C. Hofer. 1998. "The Determinants of New Venture Performance: An Extended Model." Entrepreneurship Theory and Practice 22(1): 5-29. 
Cooper, A., C. Woo, and W. Dunkelberg. 1988. "Entrepreneurs' Perceived Chances for Success." Journal of Business Venturing 3(2): 97-108.

Covin, J., and D. Slevin. 1991. “A Conceptual Model of Entrepreneurship as Firm Behavior.” Entrepreneurship Theory and Practice 16(1): 7-25.

Cramer, D. 1995. "Life and Job Satisfaction: A Two-wave Panel Study." Journal of Psychology 129(3): 261268.

Crites, S., L. Fabrigar, and R. Petty. 1994. "Measuring the Affective and Cognitive Properties of Attitudes: Conceptual and Methodological Issues." Personality and Social Psychology Bulletin 58: 60-67.

Cromie, S., and J. Hayes. 1991. "Business Ownership as a Means of Overcoming Job Dissatisfaction.” Personnel Review 20(1): 19-24.

Daily, C., and J.P. Near. 2000. "CEO Satisfaction and Firm Performance in Family Firms: Divergence Between Theory and Practice." Social Indicators Research 51: 125-170.

Davis, J. 1999. Cumulative General Social Survey 1972-1998. Inter-university consortium for political research: Ann Arbor, MI.

DeSimone, L., G. Hatsopoulos, W. O’Brien, B. Harris, and C. Holt. 1995. "How Can Big Companies Keep the Entrepreneurial Spirit Alive?" Harvard Business Review 73(6): 183-192.

Dess, G., and G. Lumpkin. 2005. "The Role of Entrepreneurial Orientation in Stimulating Effective Corporate Entrepreneurship." Academy of Management Executive 19(1): 147-156.

Edwards, J. 1991. Person Job Fit: A Conceptual Integration, Literature Review, and Methodological Critique. Wiley: New York, NY.

Edwards, J., and R. Harrison. 1993. "Job Demands and Worker Health: Three-dimensional Reexamination of the Relationship Between Person - Environment Fit and Strain.” Journal of Applied Psychology 78(4): 628648.

Ensley, M., A. Pearson, and A. Amason. 2002. "Understanding the Dynamics of New Venture Top Management Teams: Cohesion, Conflict, and New Venture Performance." Journal of Business Venturing 17: 365-386.

Fischer, E., and A. Reuber. 2003. "Support for Rapid-Growth Firms: A Comparison of the Views of Founders, Government Policymakers, and Private Sector Resource Providers." Journal of Small Business Management 41(4): 346-365.

Fordyce, M. 1988. "A Review of Research on the Happiness Measures: A Sixty Second Index of Happiness and Mental Health." Social Indicators Research 20: 355-381.

Gartner, W., K. Shaver, N. Carter, and P. Reynolds (eds.). 2004. Handbook Of Entrepreneurial Dynamics: The Process Of Business Creation. SAGE Publications: Thousand Oaks, CA.

Garvin, D. 2004. "What Every CEO Should Know About Creating New Businesses." Harvard Business Review 82(7/8): 18-21.

Griffeth, R., P. Hom, and S. Gaertner. 2000. "A Meta-analysis of Antecedents and Correlates of Employee Turnover: Update, Moderator Tests, and Research Implications for the Next Millennium." Journal of Management 26(3): 463-488.

Guzzo, R., and E. Salas (eds.). 1995. Team Effectiveness and Decision Making in Organizations. Jossey-Bass: San Francisco, CA.

Hill, R., and J. Hlavacek. 1977. "Learning from Failure: Ten Guidelines for Venture Management." California Management Review 19(4): 5-16.

Hills, G., and R. Singh. 2004. "Opportunity Recognition.” In W.B. Gartner, K.G. Shaver, N.M. Carter, and P.D. Reynolds (eds.), Handbook of Entrepreneurial Dynamics: The Process of Business Creation. Sage: Thousand Oaks, CA.

Holland, J. 1985. Making Vocational Choices: A Theory of Careers (2nd ed.). Prentice-Hall: Englewood Cliffs, NJ.

Hom, P., and R. Griffeth. 1995. Employee Turnover. South-Western: Cincinnati, OH.

Hornsby, J., D. Naffziger, D. Kuratko, and R. Montagno. 1993. “An Interactive Model of the Corporate Entrepreneurship Process.” Entrepreneurship Theory and Practice 17(2): 29-37.

Hulin, C., M. Roznowski, and D. Hachiya. 1985. "Alternative Opportunities and Withdrawal Decisions: Empirical and Theoretical Discrepancies and an Integration.” Psychological Bulletin 97: 233-250.

Johnson, K.L., W. Danis, and M. Dollinger. 2008. "Are You an Innovator or Adaptor? The Impact of Cognitive Propensity on Venture Expectations and Outcomes." New England Journal of Entrepreneurship 11(2): 2945.

Judge, T., and G. Ferris. 1992. "The Elusive Criterion of Fit in Human Resource Staffing Decisions." Human Resource Planning 15(4): 47-67.

Kirzner, I. 1997. "Entrepreneurial Discovery and the Competitive Market Process: An Austrian Approach." Journal of Economic Literature 35(1): 60-85. 
Klavans, R., M. Shanley, and W. Evan. 1985. "The Management of Internal Corporate Ventures: Entrepreneurship and Innovation." Columbia Journal of World Business 20(2): 21-27.

Kristof, A. 1996. "Person-organization Fit: An Integrative Review of its Conceptualizations, Measurement, and Implications." Personnel Psychology 49: 1-49.

Krueger, N., and D. Brazeal. 1994. "Entrepreneurial Potential and Potential Entrepreneurs." Entrepreneurship: Theory and Practice 18(3): 91-104.

Larsen, R., E. Diener, and R. Emmons. 1985. “An Evaluation of Subjective Well-being Measures.” Social Indicators Research 17: 1-17.

Lee, C., K. Lee, and J. Pennings. 2001. "Internal Capabilities, External Networks, and Performance: A Study of Technology-based Ventures.” Strategic Management Journal 22: 615-640.

Lee, T., T. Mitchell, L. Wise, and S. Fireman. 1996. "An Unfolding Model of Voluntary Employee Turnover." Academy of Management Journal 39(1): 5-36.

Luther, J. 1984. "How CEOs Can Help Improve the Odds for Market Success.” Management Review 73(7): 1824.

Mallon, M. 1998. “The Portfolio Career: Pushed or Pulled to it?” Personnel Review 27(5): 361-377.

Matthews, C., and S. Human. 2004. "The Economic and Community Context for Entrepreneurship: Perceived Environmental Uncertainty.” In W.B. Gartner, K.G. Shaver, N.M. Carter, and P.D. Reynolds (eds.), Handbook of Entrepreneurial Dynamics: The Process of Business Creation. Sage: Thousand Oaks, CA.

McFadzean, E., A. O'Loughlin, and E. Shaw. 2005. "Corporate Entrepreneurship and Innovation Part 1: The Missing Link.” European Journal of Innovation Management 8(3): 350-372.

Mobley, W. 1977. "Intermediate Linkages in the Relationship Between Job Satisfaction and Employee Turnover." Journal of Applied Psychology 62: 237-240.

Murphy, G., J. Trailer, and R. Hill. 1996. "Measuring Performance in Entrepreneurship Research." Journal of Business Research 36(1): 15-23.

Powell, J., and C. Bimmerle. 1980. "A Model of Entrepreneurship: Moving Toward Precision and Complexity." Journal of Small Business Management 18(1): 33-36.

Putnam, R., R. Leonardi, and R. Nanetti. 1993. Making Democracy Work. Princeton University Press: Princeton, NJ.

Reynolds, P.D. 2000. "National Panel Study of U.S. Business Startups: Background and Methodology.” In J.A. Katz (ed.), Advances In Entrepreneurship, Firm Emergence, And Growth. JAI Press: Stamford, CT.

Ross, J. 1987. "Corporations and Entrepreneurs: Paradox and Opportunity." Business Horizons 30(4): 76-80.

Ruamsook, K., D. Russell, and E. Thomchick. 2007. "U.S. Sourcing from Low-cost Countries: A Comparative Analysis of Supplier Performance.” Journal of Supply Chain Management 43(4): 16-30.

Schjoedt, L., and K. Shaver. 2007. "Deciding on an Entrepreneurial Career: A Test of the Pull and Push Hypotheses Using the Panel Study of Entrepreneurial Dynamics Data1," Entrepreneurship Theory and Practice 31(5): 733-738.

Schmidt, R. 1997. "Managing Delphi Surveys Using Nonparametric Statistical Techniques.” Decision Sciences 28(3): 763-774.

Schneider, B. 2001. "Fits About Fit," Applied Psychology: International Review 50(1): 141-152.

Schumpeter, P. 1934. The Theory of Economic Development. Harvard University Press: Cambridge, MA.

Shah, C., M. Zegveld, and L. Roodhart. 2008. "Designing Ventures That Work." Research Technology Management 51(2): 17-25.

Shane, S., E. Locke, and C. Collins. 2003. "Entrepreneurial Motivation," Human Resource Management Review 13: 257-279.

Shane, S., and S. Venkataraman. 2000. "The Promise of Entrepreneurship as a Field of Research." Academy of Management Review 25(1): 217-227.

Shapero, A., and L. Sokol. 1982. "The Social Dimensions of Entrepreneurship.” In C.A. Kent, D.L. Sexton and K.H. Vesper (eds.), Encyclopedia Of Entrepreneurship. Prentice Hall: Englewood Cliffs, NJ.

Sharma, P., and J. Chrisman. 1999. "Toward a Reconciliation of the Definitional Issues in the Field of Corporate Entrepreneurship." Entrepreneurship Theory and Practice 22(3): 11-27.

Shaver, K. 2004. "Overview: The Cognitive Characteristics Of The Entrepreneur.” In W.B. Gartner, K.G. Shaver, N.M. Carter, and P.D. Reynolds (eds.), Handbook of Entrepreneurial Dynamics: The Process of Business Creation. Sage: Thousand Oaks, CA.

Simon, M., S. Houghton, and K. Aquino. 2000. "Cognitive Biases, Risk Perception, and Venture Formation: How Individuals Decide to Start Companies.” Journal of Business Venturing 15(2): 113-134.

Sommers, W., and A. Koc. 1987. "Why Most New Ventures Fail (and How Others Don't)." Management Review 76(9): 35-39. 
Stewart, W., J. Carland, J. Carland, W. Watson, and R. Sweo. 2003. "Entrepreneurial Dispositions and Goal Orientations: A Comparative Exploration of United States and Russian Entrepreneurs." Journal of Small Business Management 41(1): 27-46.

Stoner, C., and F. Fry. 1982. "The Entrepreneurial Decision: Dissatisfaction or Opportunity?” Journal of Small Business Management 20(2), 39-44.

Sykes, H., and Z. Block (1989). “Corporate Venturing Obstacles: Sources And Solutions.” Journal of Business Venturing 4(3): 159-167.

Thornberry, N. 2003. "Corporate Entrepreneurship: Teaching Managers to be Entrepreneurs." The Journal of Management Development 22(4): 329-344.

Utsch, A., and A. Rauch. 2000. "Innovativeness and Initiative as Mediators Between Achievement Orientation and Venture Performance.” European Journal of Work and Organizational Psychology 9(1): 45-62.

Wanous, J., A. Reichers, and M. Hudy. 1997. "Overall Job Satisfaction: How Good are Single-item Measures?" Journal of Applied Psychology 82: 247-252.

Ware, G. 1973. "A General Statistical Model for Estimating Future Demand Levels of Data-Base Utilization Within an Information Retrieval Organization." Journal of the American Society for Information Science 24(4): 261-264. 


\section{Contributors}

MARY K.ASKIM-LOVSETH is an associate professor and chair of the Department of Marketing and the Morrison Faculty Fellow in the College of Business and Public Administration. Her research interests include entrepreneurial failure, credit card solicitation practices regarding college students, website evaluation, and consumption practices.

ANA MARIA BOJICA is an assistant professor of Business Administration at the University of Granada, Spain. Her research interests are corporate entrepreneurship, knowledge acquisition and strategic alliances.

NANCY BRASSARD est professeure en gestion des ressources humaines à l'École nationale d'administration publique. Ses champs d'intérêt concernent principalement la gestion des compétences. Son expertise en docimologie lui permet de travailler davantage en évaluation des compétences, important axe de la gestion des ressources humaines.

RICHARD A. FEINBERG is a professor of Consumer and Family Sciences. He has published extensively in the areas of psychology, consumer behavior, and retailing.

MARÍA DEL MAR FUENTES-FUENTES is a full professor of Business Administration at the University of Granada, Spain. Her main research interests consist of female entrepreneurship and academic entrepreneurship.

KEVIN L. JOHNSON is an assistant professor of Management and Entrepreneurship in the Opus College of Business at the University of St. Thomas, where he teaches both graduate and undergraduate Strategy and Management courses. His research interests include corporate entrepreneurship, business strategy and innovation, and new venture management.

SCOTT LATHAM is an assistant professor at the University of Massachusetts Lowell and earned a $\mathrm{Ph} . \mathrm{D}$. in business policy and strategy in 2005. His general research and consulting interests focus on the process of creative destruction - the interplay of innovation, entrepreneurship, and the business cycle that transforms industries.

NORMAND PETTERSEN est professeur associé au Département des sciences de la gestion, Université du Québec à Trois-Rivières. Ses publications portent notamment sur la sélection du personnel, les modèles de compétences et les instruments de mesure en contexte de gestion des ressources humaines.

LÁZARO RODRÍGUEZ-ARIZA is a full professor in the Accounting Department at the University of Granada, Spain. He is interested in accounting management, financial mechanisms for entrepreneurship and minority entrepreneurship.

MATILDE RUIZ-ARROYO is a researcher in the Department of Business Administration at the University of Granada, Spain. Her research interests are related to academic entrepreneurship and women's entrepreneurship.

CHRIS STREET is an associate professor in the Hill School of Business at the University of Regina where he teaches in the Entrepreneurship program. His research interests involve corporate entrepreneurship and small business networks. Chris received his Ph.D. from the Queen's School of Business in Kingston, Canada.

STEVEN TELLO is an assistant professor of Management and Entrepreneurship at the University of Massachusetts Lowell and is also associate director of the Massachusetts Medical Device Development Center (M2D2). His research interests include technology innovation and entrepreneurship, organizational change and innovation management. 
CINDY WU is an associate professor of Management and Entrepreneurship in the Hankamer School of Business, where she teaches undergraduate Human Resource Management and Organizational Behavior. Her research interests are in leadership, employee motivation and emotions, and strategic human resource management.

RONIT YITSHAKI is an assistant professor in the Department of Sociology at Bar Ilan University, Israel. Her research focuses on entrepreneurial identity, entrepreneurs' emotional intelligence and leadership, and the relations between venture capitalists and entrepreneurs.

YI YANG is an assistant professor at the University of Massachusetts Lowell and received her Ph.D. in organization and strategy from Drexel University. Her research interests include corporate venturing and entrepreneurship, organizational learning, technology management, and decision-making process. 